\title{
Environmental Awareness among + 1 class school students of Hoshiarpur District
}

\author{
Jagjit Kaur \\ Research Scholar (JRF) Panjab University, Chandigarh
}

\begin{abstract}
The present paper attempts to determine the degree of environmental consciousness or among +1 class school students of Hoshiarpur District. The study was conducted on the sample of 200 senior secondary students (100 opting for Science and 100 opting for Humanities) from four schools (two Government and two Private) of Hoshiarpur District, and data were collected through descriptive survey method using standardized Environmental Concept Achievement test (ECAT). The major findings were: (1) 79.5\% of the students possessed average and higher environmental awareness. $69.5 \%$ had average environmental awareness and $10 \%$ had higher environmental awareness. Only $20.5 \%$ of the total sample was having lower environmental awareness i.e. they were not aware of the environmental issues. (2) A significant difference in environmental awareness among boys and girls of senior secondary school was determined. Girls were more aware than boys. (3) Lastly, It was determined that there existed a significant difference in environmental awareness among science and arts students of senior secondary schools of Hoshiarpur District. Science students were more conscious of their environment than arts students.
\end{abstract}

Keywords: Environmental awareness or consciousness.

\section{INTRODUCTION}

Our planet Earth is facing serious global problems relating to exploitation and degradation of natural resources, deforestation, pollution, depletion of soil, biodiversity loss, fresh water scarcity, massive industrialization, nuclear disasters and many more. Such issues are of major concern these days. This is all due to excessive human involvement in the natural processes.

These existing global issues have reached the peak and lead to serious health problems and drastic impact on the environment. It also effects the economic growth inevitably. This massive exploitation and down gradation of our environment has provoked different nations and organizations to look into the matter with serious concern and take crucial steps for the conservation and protection of the earth's environment. The environmental concern should be realized as early as possible for better survival and well being of mankind. Existing environmental catastrophe can only be set down through education system because it is only the education system that can inculcate the environmental awareness among citizens. Moreover, various educators and environmental specialists have indicated the importance of education system in creating environmental friendly society. United Nations Conference on Environment and Development (UNCED), held in Rio de Janeiro in 1992, agreed to a global environment and development agenda for the 21st century, called Agenda 21. In Agenda 21 it was stated "Education, including formal education, public awareness and training should be recognized as a process by which human beings and societies can reach their fullest potential. Education is critical for promoting sustainable development and improving the capacity of people to address environment and development issues". In this regard, various steps have been executed to enact environmental awareness among masses by providing environmental education. Governments of different nations have made it compulsory to teach environmental education at school levels. It should be an integral part of the existing curriculum. This will help in encouraging students to protect and conserve their immediate environment at the early ages. According to NCF (2005), environmental education should be the main subject in the curriculum. Supreme Court also directed the education system to make strategic plans to inculcate environmental education as a mandatory subject in all classes. This will result in developing environmental awareness among youths. The foremost objective of the environmental education is creating awareness and sensitivity towards environmental concerns among individuals and social groups. It may involve campaigning to make audience aware about environment and media to reach inaccessible areas. Next is the knowledge that basically helps individuals and society to understand and comprehend environment and its associate issues followed by developing positive attitude towards conserving biodiversity and acquire set of values and motivation towards protecting environment and taking active part in environmental protection, conservation and improvement programs. Last but not the least is inculcating such skills among social groups that help them in recognizing and understanding problems regarding environment and taking essential measures to solve them. 
In general, the aim of environmental awareness or consciousness is to make people realize the value and significance of environment in our life, importance of biotic and non biotic elements such as soil, land, plants, air, water, natural resources etc and the impact of its degradation on mankind.

Hence, environmental education should aim at providing quality environmental awareness among students and creates such circumstances in which people participate by their own to put their potential towards environmental protection. Proper environmental awareness and development programs should be organized by the nations at international, national and local levels so that each and every individual can participate. Environmental education at school level should uplift the social attitude and behavior of young budding towards environment and acculturate in them the global concern about environmental issues. Environmental education has a goal to develop a world population who is aware of problems associated with the environment and has skills, knowledge, motivation, attitude and commitment to work individually and in groups to find solution to environmental problems and to prevent new ones coming in the way.

Environmental education as a compulsory subject should be included in curriculum at school level so that students opting for humanities would be benefited. Region specific instructional material regarding environmental education should be developed. The objectives of environmental education categorized by UNESCO as: awareness (sensitivity to the environment and its allied problems), knowledge (to acquire variety of experiences), attitudes (to acquire set of values and feelings of concern for the environment), skills (for identifying and solving environmental problems) and participation (to be involved at all levels in working towards the resolution of environmental problems). In a nutshell, if we are really aspiring a safe and healthy planet, we need to educate the whole population environmentally. The senior secondary stage is an important phase of education as from here the students will enter the world of adult. Hence it is imperative to find out the level of environmental awareness among senior secondary students and what kind of efforts is needed in changing their mindset towards environment.

\section{REVIEW OF RELATED LITERATURE:}

On an International Level, concern for the environment was the subject of a UN Conference in Stockholm in 1972, attended by 114 nations. Out of this meeting, UNEP (United Nations Environment Program) and the follow up United Nations Conference on environment were developed in 1992, plus other International organizations in support of environment cooperation (NAFTA), the European Environment Agency (EEA), and the Intergovernmental Panel on Climate Change (IPCC). UNESCO in Cooperation with UNEP launched the international environmental education program (IEEP). According to National Environmental Education Advisory Council (NEEAC) (1996), it is generally agreed that environmental education is a process that creates awareness and understanding of the relationship between humans and their many environments. Singh. R and Abbas. Y.M. (2012) concluded from their research work that students had high level of environmental knowledge and positive attitudes towards the environment, but low level participation in environmental protection activities. Das and Banerjee (2014) conducted a study to determine the environmental awareness among secondary school students in West Bengal and concluded that there was no significant difference in environmental awareness among higher secondary school students in respect of their gender, locality and academic stream. Pasha. J (2015) studied the environmental awareness among secondary school students in relation to caste, father occupation and class of study in Warangal District and revealed that there is a significant impact of caste, father occupation and class on environmental awareness among students. Usha.et. al. (2015) formulated a research work in which they studied the attitude and awareness of college going undergraduate students towards environment. Overall level of awareness was found to be average. Number of students with high level of awareness is found to be extremely low whereas number of students with low level of awareness is found to be fairly high. Bala. R (2015) made an attempt to study the comparison of environmental awareness among urban and rural secondary school students and concluded that there exists a significant difference in two variables. Ali (2016) did a research to determine environmental awareness among students of technical courses of A.M.U and revealed that female students were more aware than the male students of technical courses of A.M.U.

\section{EMERGENCE OF THE PROBLEM:}

India is the second most populated country in the world. It has $2.4 \%$ of the total land area accommodating $16 \%$ of the world's population. It exerts excessive pressure on natural resources. In addition to this, the inappropriate human actions towards environment results in the extreme hazards for the present and coming generations. Human beings are utilizing resources at a fast pace in an unsustainable manner without taking into considerations the after effects. This has led to think about the protection and maintenance of resources and using them sustainably for the sake of coming generations and conservation of the environment. So, the goal of protecting environment can only be achieved through education. Education is such a weapon which we can use and change the world. Through environmental education we can sensitize the young minds 
and make them aware about their environment and its related issues. Environmental education according to UNESCO must have the objectives of providing knowledge, skills, attitude and awareness about environment. So, environmental education should be the core subject in the curriculum of the school system to inculcate environmental consciousness among students at the very early age of their lives. The already existing curricula at all levels of the school education should have the mandatory subject of environmental education. The present study is going to deal with senior secondary school students because these students are at the edge of entering into the world of youths. They are very active and curious. So this is the age at which they can imbibe such environmental issues into their mind and implement necessary actions for the protection of the environment. Moreover, there is a need for studying the environment awareness of +1 class school students in relation to their gender and academic stream.

\section{OBJECTIVES}

Major objectives of the present study are as follows:

1. To determine the environmental awareness among +1 class school students of Hoshiarpur district

2. Comparison of the environmental awareness among +1 class boys and girls.

3. Comparison the environmental awareness among +1 class science and humanities group students.

\section{HYPOTHESES:}

1. Most of +1 class school students will aware of their environment.

2. There exists no significant difference in environmental awareness among boys and girls of +1 class.

3. There exists no significant difference in environmental awareness among science and arts students of +1 class.

\section{DELIMITATION OF THE STUDY:}

1. The present study is delimited to students of class +1 of senior secondary schools of Hoshiarpur District

2. The present study is delimited to the Arts and Science stream of senior secondary school students of Hoshiarpur District.

\section{METHODOLOGY}

As the study intended to see the environmental awareness among senior secondary school students of Hoshiarpur District, so the investigator had to conduct descriptive research. The investigator followed descriptive statistical methods for processing of data. Sample: In order to investigate the present problem, sample of 200 students from Private and Govt. Senior Secondary schools of Hoshiarpur District were selected giving due weightage to gender (equal boys and girls) and stream of study (equal students from arts and science stream).

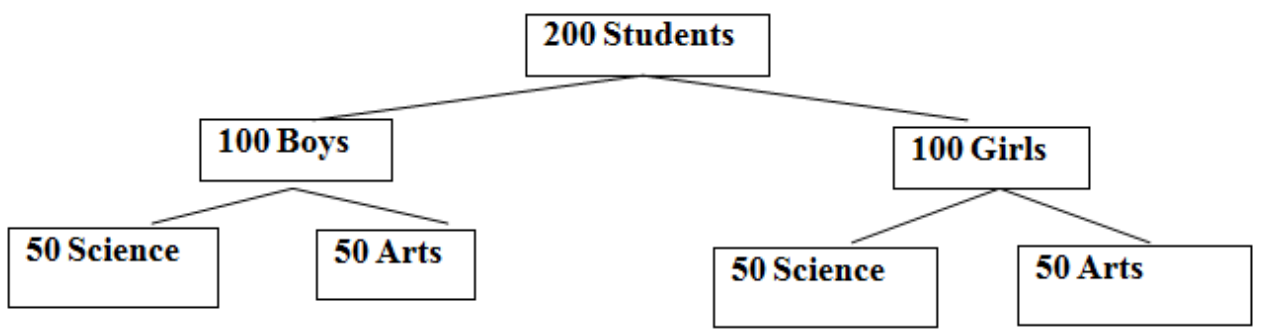

Tool Used: Concept Achievement Test (ECAT) was used for collection of data which was prepared and standardized by Dr. S.K.Bawa, Dean, Faculty of Education, Lovely University Phagwara, Punjab.

VIII. ANALYSIS AND INTERPRETATION OF DATA:

Hypothesis I: "To determine the environmental awareness among +1 class school students of Hoshiarpur district”

In this, mean and standard deviation of the whole group was calculated. After that the percentage of the students having higher environment concept achievement, average environment concept achievement and lower environment concept achievement was calculated. The results of the analysis are shown in table 1.1 
Table 1.1 Showing percentage distribution of the students classified according to their level of environmental awareness

\begin{tabular}{|c|c|}
\hline Level of Environmental Awareness & Student's \%age \\
\hline Higher Environmental Awareness & $9.8 \%$ \\
\hline Average Environmental Awareness & $69.4 \%$ \\
\hline Lower Environmental Awareness & $20.7 \%$ \\
\hline
\end{tabular}

It is evident from table 4.1 that $79.7 \%$ of the students have average and higher environmental awareness. 69.4\% have average environmental awareness and $9.8 \%$ have higher environmental awareness. Only $20.7 \%$ of the total sample is having lower environmental awareness i.e. they are not aware of the environmental issues. Hence our hypothesis that "Majority of the students will be aware of environment", stands accepted. The pictorial view of the percentage distribution of students having awareness of the environment is shown in figure 1.1

Fig 1.1 Showing percentage distribution of students classified according to their level of awareness of environment.

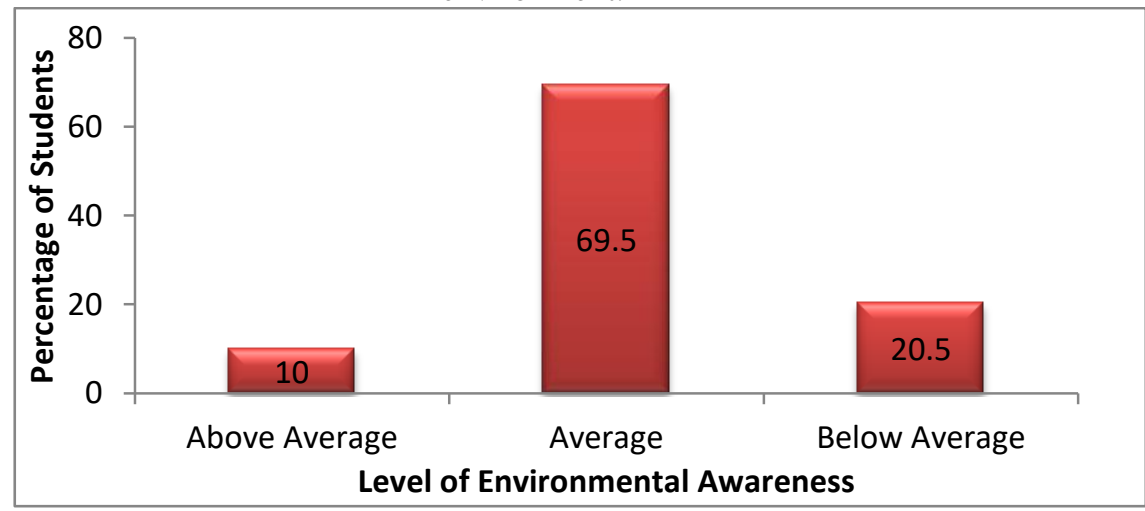

Hypothesis II: "There exists no significant difference in environmental awareness among boys and girls of +1 class."

This hypothesis was tested by calculating mean and S.D of test scores of male and female students. The hypothesis was further examined by applying ' $t$ ' test.

Table 1.2 Showing Mean, S.D and t value of boys and girls students

\begin{tabular}{|c|c|c|c|c|c|c|c|}
\hline Variable & Gender & $\mathbf{N}$ & Mean & S.D & $\mathbf{S E}_{\mathrm{D}}$ & t-Ratio & Interpretation \\
\hline \multirow{2}{*}{$\begin{array}{c}\text { Environmental } \\
\text { Awareness }\end{array}$} & Boys & 100 & 48.9 & 4.4 & \multirow[b]{2}{*}{0.62} & \multirow[b]{2}{*}{2.5} & \multirow{2}{*}{$\begin{array}{c}\text { Significant at } \\
0.05 \text { level }\end{array}$} \\
\hline & Girls & 100 & 50.45 & 4.31 & & & \\
\hline
\end{tabular}

It is clear from the table that t- ratio of significance difference of means in environmental awareness between boys and girls is 2.5> 1.96 which is statistically significant at 0.05 level of significance. Therefore hypothesis, "There exists no significant difference in environmental awareness among boys and girls of senior secondary school" stands rejected. It is found that there is significant difference in environmental awareness among boys and girls of senior secondary school students. Girls are more aware than boys. The pictorial value of the mean score of boys and girls in environmental awareness has been dispatched in figure 4.2.

Fig 1.2 Showing schematic representation of means of boys and girls students on environmental awareness.

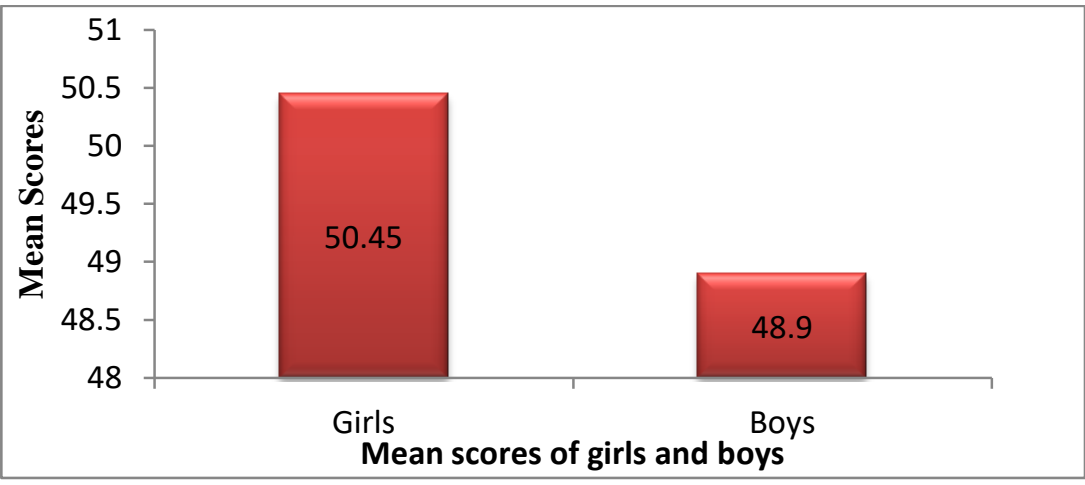


Hypothesis III: "There will be no significant difference in environmental awareness among science and arts students of +1 class".

This hypothesis was tested by calculating mean and S.D of the test scores of science and arts students of senior secondary school. The hypothesis was further examined by applying ' $t$ ' test.

Table 1.3 Showing Mean, S.D and t value of science and arts students

\begin{tabular}{|c|c|c|c|c|c|c|c|}
\hline Variables & $\begin{array}{l}\text { Educational } \\
\text { Stream }\end{array}$ & $\mathbf{N}$ & Mean & $\begin{array}{l}\text { Standard } \\
\text { Deviation }\end{array}$ & $\mathbf{S E}_{\mathrm{D}}$ & $\begin{array}{c}\text { t- } \\
\text { Ratio }\end{array}$ & Interpretation \\
\hline \multirow{2}{*}{$\begin{array}{c}\text { Environmental } \\
\text { Awareness }\end{array}$} & Science & 100 & 51 & 3.93 & \multirow[t]{2}{*}{0.50} & \multirow[t]{2}{*}{5.3} & \multirow{2}{*}{$\begin{array}{c}\text { Significant at } \\
0.05 \text { level }\end{array}$} \\
\hline & Arts & 100 & 48.35 & 3.35 & & & \\
\hline
\end{tabular}

It is clear from the table that the $\mathrm{t}$ - ratio of significance of difference of means in environmental awareness between science and arts is $5.3>1.96$ which is statistically significant at 0.05 level of significance. Therefore hypothesis, "There exists no significant difference in environmental awareness among science and arts students of senior secondary school" stands rejected. It is found that there is significant difference in environmental awareness among science and arts students of senior secondary schools of Hoshiarpur District. Science students are more aware than arts students.

Fig 1.3 Showing schematic representation of means of science and arts students on environmental awareness

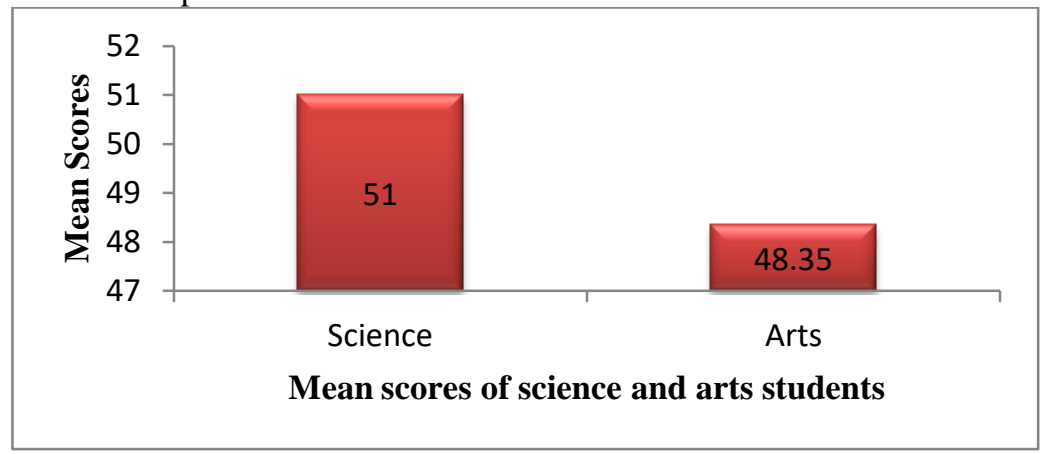

It can be concluded from the analysis and interpretation of the results that the (a) Girls are more environmentally aware than boys, (b) Science students are more aware of the environment than arts students, (c) Majority of the students of the senior secondary schools are aware of the environment.

\section{FINDINGS OF THE STUDY}

1. $79.7 \%$ of the students have average and higher environmental awareness. $69.4 \%$ have average environmental awareness and $9.8 \%$ have higher environmental awareness. Only $20.4 \%$ of the total sample was having lower environmental awareness i.e. they were not aware of the environmental issues.

2. It is concluded from the study that Girls are more aware than boys towards environment.

3. Science students are more conscious towards environmental issues than arts students.

\section{SUGGESTIONS FOR FURTHER RESEARCH:}

1. The present study was delimited to students of class +1 of senior secondary schools of Hoshiarpur District. Perhaps more valuable outcomes can be achieved if students from +2 class also.

2. The present study was delimited to senior secondary schools boys and girls of Hoshiarpur District. This research may be applied to other boys and girls of senior secondary schools of other districts also.

3. The present study was delimited to the Arts and Science stream of senior secondary school students of Hoshiarpur District. The study can be supplemented to commerce stream also.

4. The sample of the study was limited to 200 students. Therefore it is suggested that this research may be carried out on a large sample.

\section{CONCLUSION}

In conclusion, it is through this process of education that people can be sensitized about the environmental issues. The comprehension of environmental objective is very essential for the formulation, implementation and evaluation of environmental education programme. 


\section{REFERENCES}

[1] Bala. R (2015). Comparative Study of Environmental Awareness Among Secondary School Students. International Multidisciplinary e-Journal. Vol-4, (11), 166-169.

[2] Sahu. U, Roy. M, Monika, Rajkiran. (2015). Environmental Awareness Among Undergraduate Students in Rural Area. IOSR Journal of Environmental Science, Toxicology and Food Technology (IOSRJESTFT). Vol-1 (4), 27-32.

[3] Pasha. J (2015). Environmental Awareness Among Secondary School Students in Relation to Caste, Father Occupation and Class of Study in Warangal District. IRJMSH, Vol- 6 (8), 174-181.

[4] Abbas. Y. M, Singh. R. (2012). A Survey of Environmental Awareness, Attitude, and Participation Amongst University Students: A Case Study. International Journal of Science and Research (IJSR). Vol3, 1755-1760.

[5] Banerjee. N, Das. Amarnath. (2014). A Study of Environmental Awareness Among Higher Secondary School Students of Bankura District in West Bengal. International Journal of Applied Research. Vol-4 (7). 134-136.

[6] Ali. M. (2016). A Study of Environmental Awareness Among Students of Technical Courses of A. M.U. International Journal of Advancement in Education and Social Sciences. Vol-4 (1), 9-16.

[7] UNESCO (1978) Final Repor o the Intergovernmental Conference on Environmental Educaion, Organized by UNESCO in Cooperation with UNEP, Tbilisi, USSR, 14-26 October 1977, Paris: UNESCO.

[8] UNESCO/UNEP (1978). The Tbilisi declaration. Connect, UNESCO-UNEP Environmental Education Newsletter, 111(1), 1-8.

[9] Unesco-Unep., (1990). Environmentally educated teachers: the priority of priorities? Connect, 15 (1), 13.University of Toronto Press.University, Indian Edu. Abstracts, 4, Section 28, 83. 